UDC [(621.314.222.6:538.7).004.17:621.365.5].001.2

\title{
CALCULATION OF THE GEOMAGNETIC INDUCED CURRENTS IMPACT ON THE HIGH-POWER TRANSFORMER
}

\author{
IVANKOV V.F. Ph. D. in Engineering Science, Head of Dpt. at «Zaporozhtransformator» PrJSC, \\ Zaporizhzhia, Ukraine, e-mail: ivankov.viktor@gmail.com; \\ BASOVA A. V. Ph. D. in Engineering Science, Senior Engineer at «Zaporozhtransformator» PrJSC, \\ Zaporizhzhia, Ukraine, e-mail: awbasova@gmail.com.
}

Purpose. Determination of resistance of a powerful power transformer to the action of geomagnetic induced currents (GIC) and structural measures for its increase, if necessary.

Methodology. An analytical calculation of the magnetization current (MC) is applied, which under the action of geomagnetic induced currents is excited in addition to the rated current in the higher voltage winding. Analytical and numerical calculations of the magnetic field and the losses, and computational-empirical methods for estimation of the temperature rises are used.

Findings. For a five-core transformer with a power of 630 MVA under the GIC effect, the increased losses and heating of structural elements on the cores of the magnetic system, the tank, and the increased sound level are determined.

Originality. For the case of orthogonal property of the vectors of winding rated currents and the vectors of harmonic components of the peak unbalanced MC, the Joule losses are represented by the sum of the losses due to these currents using the increase factors for ohmic losses in non-magnetic and ferromagnetic structural parts, which depend on MC harmonic spectrum.

Practical value. The stability of the transformer under test to the given level of GIS was confirmed, and structural measures for its increase were recommended. The tested methods can be used in the computational design, in the study of real cases of equipment operation.

Key words: transformers; geomagnetic induced currents; losses; temperature rises; calculations.

\section{INTRODUCTION}

Varying solar magnetic activity causes the responses of geo-magnetic field, which induce electrical potentials on the Earth's surface. In case of considerable distances between the ground points of the winding neutrals of transformers, shunt reactors and other equipment associated with HV lines, geomagnetic inducted currents (GIC) flow through the conductors of long-distance power transmission lines connected to electrical equipment - fig. 1 from the Standard [1].

In the most events such currents are considered as quasi-fixed (DC) currents IDC=IGIC/3, which are closed in the transformer higher-voltage windings (HV) in addition to operational alternating currents (AC). Observation within operation and theoretical researches demonstrate that GIC effects causes overheating of the structural elements, especially, tie bars and clamping plates of the magnetic system (MS) [1], and lead to increased sound level.

The requirement of evaluation of thermal withstand capability of the power transformers exposed to GIC is set by new Standard [1]. Therefore, study of GIC effect on the high-power transformer is of great current interest.

(C) Ivankov V.F., Basova A.V., 2019

DOI 10.15588/1607-6761-2019-4-1

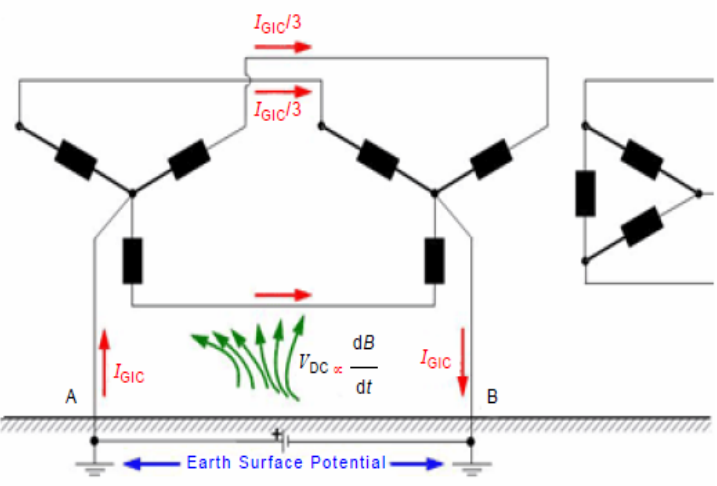

Figure 1. GIC flow into a power transformer

\section{II.ANALYSIS OF RESEARCH AND PUBLISHED PAPERS}

The issues of GIS occurrence and effects on the electrical equipment of the power systems, in particular on the power transformers are considered in [2]. It is noted that if the so-called methods of active blocking or compensation of direct currents are not applied [5], [13], MS saturation due to superposition of AC and DC magnetic fluxes is possible in the transformers with five- core 
three-phase or single-core single-phase designs, and generation of unbalanced nonsinusoidal magnetizing current (MC) in HV windings [4]. Generation of MC with halfperiod peaks is illustrated in fig. 2 from [5], [6].

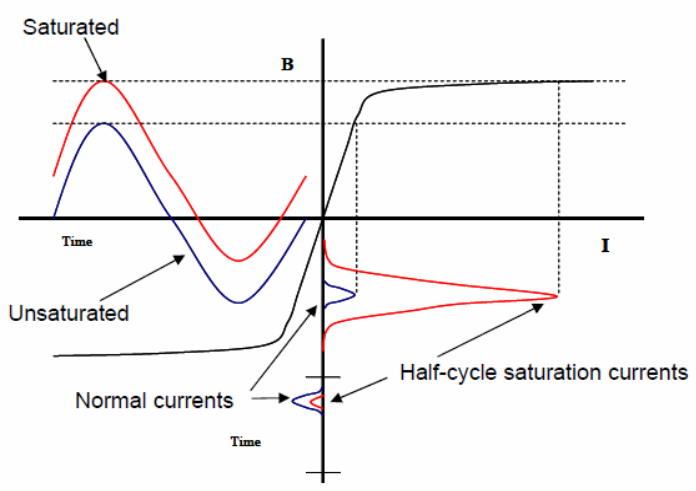

Figure 2. Induction in unsaturated and saturated core, and magnetizing current

Studies of GIC effects on the transformer are preceded by theoretical assessments and direct measurements of induced electric potentials, DC currents duration and magnitude at probable sites of equipment operation [4], [5], [13]. Based on the results of such studies, the customers declare the appropriate requirements for the manufacturers. DC current duration and magnitude can be considered as necessary and sufficient for evaluation of the equipment withstand strength under GIC effect [8], [9].

Thus, in [8], MC in HV at currents of 25/3, 50/3, $100 / 3$ A DC is analyzed for 292 MVA transformer, and in [12], MC is analyzed at 50/3 A DC for 550 MVA transformer. In [15], $65 \mathrm{~A} \mathrm{DC}$ is considered to be critical for the tank temperature rise for the transformer rated for 400 MVA capacity.

To evaluate MC in HV winding the well-known papers contain description of T-shaped single- or threephase equivalent circuit with lumped parameters [2]. It comprises of the circuit of parallel-connected inductive excitation impedances of MS and windings connected in series to HV winding ohmic and inductive resistance.

Simultaneous effect of alternating and direct voltage on the specified nonlinear circuit is investigated by numerical methods using the ATP-EMTP, Mathlab software. In this case, MS magnetizing is simulated with consideration of the hysteresis (flux current) loop [11], [15], [16] or according to normal magnetization curve of electrical steel [12].

The papers [2], [3], [8] describe analytical evaluation of the amplitudes and the harmonic composition of HV winding MS peak current. The valid assumption was made for high-power transformers which ohmic resistance of $\mathrm{HV}$ winding is much less than its dynamic inductance. Due to the saturation of electrical steel of MS core, this inductive resistance is determined by winding inductance without core $x_{\text {sat }}=\omega L_{\text {sat }}, \omega=2 \pi f$.
Peak MC $i_{\text {mag }}(t, \alpha)$ at saturation angle $\alpha$ of $\mathrm{HV}$ winding rated for phase voltage $U$ is generated at time interval $\pi-\alpha \leq \omega t \leq \pi+\alpha$ and determined by expression [3]

$$
i_{\text {mag }}(t, \alpha)=-A(\cos \omega t+\cos \alpha),
$$

where $A=\sqrt{2} U / x_{\text {sat }}$, and saturation angle $\alpha$ is obtained from condition of equality of DC $\mathrm{I}_{\mathrm{DC}}$ and the zero-th harmonic of expansion of the function (1)

$$
I_{D C}=i_{0}=A(\sin \alpha-\alpha \cos \alpha) / \pi .
$$

Maximum $\mathrm{MC}$ value in $\mathrm{HV}$ winding is equal to

$$
i_{\text {max }}=A(1-\cos \alpha) \text {. }
$$

MC phase is determined by applied voltage phase, thus, maximum value of balanced operational currents of $\mathrm{LV}$ and $\mathrm{HV}$ windings is offset by the angle $\pi / 2$ or by another, so-called, load angle $\varphi$. This leads to the fact that within different time intervals the transformer active part is exposed to different magnetic fields. The first magnetic field is due to balanced sinusoidal operational currents of the winding in case of unsaturated MS. The second is due to unbalanced MC in HV winding.

The magnetic field of operational currents is defined as leakage field, that is, provided that the total ampereturns of the windings are equal to zero. For its calculation, the sufficiently well-known analytical calculation models are widely used [17], [20], including, for example, the plane-parallel model of the winding system taking into account MS core using the method of mirror reflections.

The magnetic field of $\mathrm{HV}$ winding unbalanced $\mathrm{MC}$ is solenoidal field and the above model should be considered as unacceptable for its calculation. Therefore, when studying GIC effects on the transformers, the finiteelement (FEM) analysis methods are used, which assume both the balance and the unbalance of total ampere-turns in the windings and various levels of MS saturation. For example, two-dimensional axisymmetrical FEM models were used to calculate the magnetic fields within 292 MVA autotransformer windings [8], in the region of the windings and the tank of transformer rated for $550 \mathrm{MVA}$ [12]. In [15], the analytical model of the cylindrical winding in air is used to calculate MC magnetic fields.

In this paper, to calculate the magnetic field, both for balanced operational currents, and for HV MC winding, the single-core $\mathrm{M}-\mathrm{CC}$ model is employed (closed cylindrical model) of one or several windings arranged in the cylindrical slot [20].

For the known values of the magnetic field, the following calculations of losses and temperature rises are performed using numerical-analytical and computationalempirical methods [17] - [20], implemented as the software in the computer-aided design subsystem [20]. The calculation features related to the mode with DC currents are shown in the appropriate sections of this paper. 
For the purpose of calculation of the magnetic fields, the losses, and the temperature rises, it is effective to use two- and three-dimensional numerical methods of finiteelement modeling, that is, FEM models [20]. However, the relevant studies have shown that application and verification of operation results of known invariant FEM systems for analysis of electromagnetic processes with unharmonic variation of excitation currents introduce the considerable methodological complexity, description of which is beyond the scope of this paper. This is especially true for the bodies of limited size with non-linear surfaceeffect, and welded structural elements. Therefore, this paper represents the results of the numerical simulation only for the mode of harmonic (sinusoidal) rated currents using the methods presented in [20]. It is also important to point out the fact that time constants for temperature rises of the windings and the structural elements is much less than those related to oil in the tank. For example, in fig. 3 from [5] it is shown that temperature rises of the tank with a slight delay (the minutes) correspond to GIC variations, and top-oil temperature in the tank remains unchanged for more than 1.5 hours. Therefore, the assumption is made in the present paper that oil temperature in the transformer tank will be unchanged even in the case of the total losses increase due to GIC effect.

The mentioned brief review of the problem demonstrates the importance of the most accurate evaluation of all critical electromagnetic and thermal parameters of the transformer at rated operating mode, and, if possible, it should be implemented both based on the results of calculation analyses and on experimental studies during type testing, as well as taking into account evaluation of changing of these parameters at specific levels of GIC effects expected in operation.

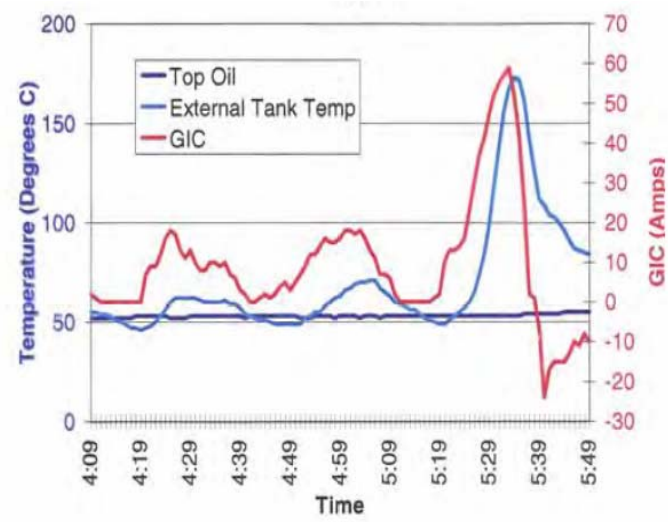

Figure 3. GIC, temperature of the tank and oil in the tank

\section{OBJECTIVE}

The paper is purposed for evaluation of withstand strength of the high-power transformer affected by geomagnetic induced currents, and recommendation of the constructive measures aimed at improvement of withstand strength, if appropriate.

\section{PRESENTATION OF THE MAIN MATTER AND ANALYSIS OF THE OBTAINED RESULTS}

Object, conditions. For the purpose of this paper, the TDC-630000/500 five-core transformer type with OFAF oil-forced cooling system is used as the object. HV winding of the transformer under study is characterized by phase rated voltage of $525 / \sqrt{3} \mathrm{kV}$, rated current of $346.4 \mathrm{~A}$; fundamental frequency $\mathrm{fl}=50 \mathrm{~Hz}$. The customer specified in the inquiry for this transformer the geomagnetic induced currents (GIC) flowing in $\mathrm{HV}$ winding neutral having the value $\mathrm{IDC}=30 / 3=10$ A per phase and the duration $30 \mathrm{~min}$. To demonstrate the changes of current parameters during DC current multiplication, the 20 and 30 A values were considered.

Magnetizing currents. Using $\mathrm{M}-\mathrm{CC}$ model, the inductance Lsat $=1.8$ Henry, and, following the expressions (1) - (3), - MC parameters in HV winding were determined. The results are represented in fig. 4 and in tab. 1, tab. 2. MC time dependences as for DC currents of 10, 20, $30 \mathrm{~A}$ are shown by means of dotted line, dashed line and solid line, respectively.

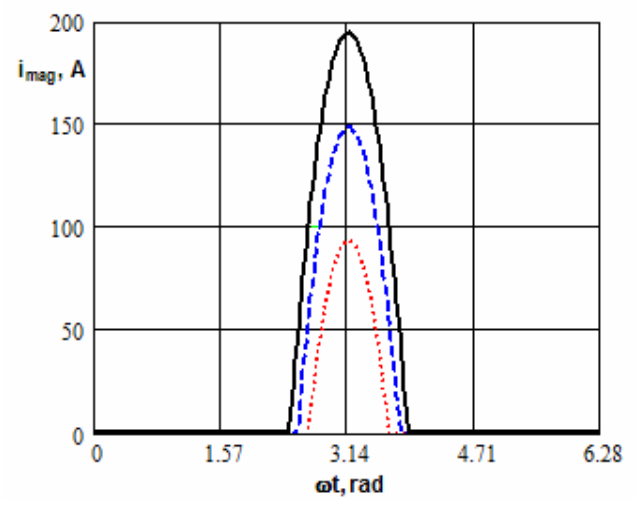

Figure 4. $\mathrm{MC}$ time dependences $i_{\text {mag }}(t, \alpha)$ at DC currents $10,20,30 \mathrm{~A}$

In tab. 1, the values of saturation angles, maximum peak current values $i_{\max }$, and effective values of the first $i_{1}$ harmonic of the cosine development of time function of the current are given for a number of DC current values (1).

Table 1. MC, increase factors of the losses

\begin{tabular}{|c|c|c|c|c|c|c|}
\hline $\mathrm{I}_{\mathrm{DC}}, \mathrm{A}$ & $\alpha, \mathrm{rad}$ & $i_{\max }, \mathrm{A}$ & $i_{1}, \mathrm{~A}$ & $k_{i^{2} R}$ & $k_{N}$ & $k_{F}$ \\
\hline 10 & 0.503 & 94.0 & 19.5 & 3.4 & 31.0 & 7.5 \\
\hline 20 & 0.637 & 148.9 & 38.4 & 2.7 & 16.7 & 5.1 \\
\hline 30 & 0.733 & 194.7 & 57.0 & 2.3 & 11.8 & 4.0 \\
\hline
\end{tabular}

Table 2 contains the relative values referred to the current $i_{1}$ for the harmonics $n$ from 2 to 10 . The current parameters almost linearly depend on DC currents, having the distinction due to the changes in the saturation angle. 
Table 2. MC harmonics $i_{n} / i_{1}$

\begin{tabular}{|l|l|l|l|}
\hline \multirow{2}{*}{$\mathrm{n}$} & \multicolumn{3}{|c|}{$\mathrm{I}_{\mathrm{DC}}, \mathrm{A}$} \\
\cline { 2 - 4 } & 10 & 20 & 30 \\
\hline 2 & 0.93 & 0.88 & 0.85 \\
\hline 3 & 0.81 & 0.71 & 0.63 \\
\hline 4 & 0.67 & 0.51 & 0.39 \\
\hline 5 & 0.51 & 0.31 & 0.18 \\
\hline 6 & 0.35 & 0.14 & 0.02 \\
\hline 7 & 0.21 & 0.01 & 0.07 \\
\hline 8 & 0.09 & 0.06 & 0.09 \\
\hline 9 & 0.00 & 0.09 & 0.06 \\
\hline 10 & 0.06 & 0.07 & 0.02 \\
\hline
\end{tabular}

Using the dotted land dashed lines, fig. 5 shows time dependences of rated currents in $\mathrm{LV}$ and $\mathrm{HV}$ windings at AC mode, and using the solid line, - sum of rated and magnetizing currents in HV winding at $30 \mathrm{~A}$ DC current and angle $\varphi=\pi / 2$. The values are shown in relative units as referred to amplitude of $\mathrm{HV}$ winding rated current, LV winding current is adjusted by the turns. Further, the combined mode of AC and DC is designated as $\mathrm{AD}$ mode.

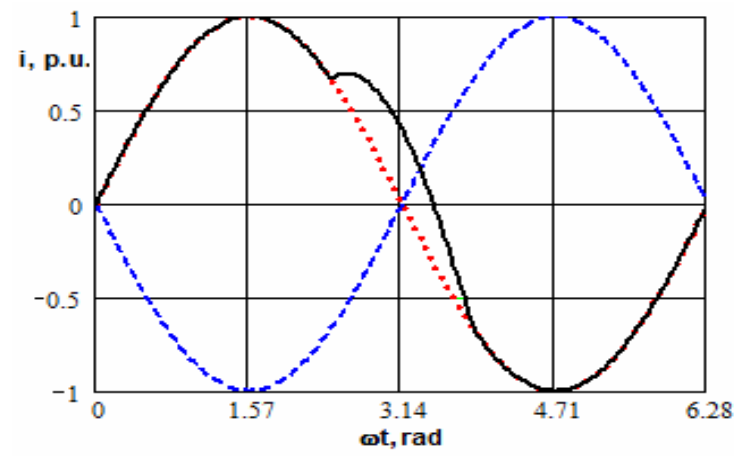

Figure 5. Time dependences of rated currents in the windings and of the resultant (net) current in HV

It was determined in [8] that «for a unit load power factor, $\mathrm{MC}$ and load current are lagged by $90^{\circ}$, and the heat losses for the total current is the sum of the heat losses for each current.

$$
i_{p(r m s)}^{2}=I_{n p}^{2}+i_{m(r m s-D C)}^{2},
$$

where $i_{p}$ is primary current, $I_{n p}$ is rated primary current.

If load power factor is $\cos (\varphi), \mathrm{MC}$ and load current will lag by $(90-\varphi)^{\circ}$ and

$$
i_{p(r m s)}^{2}=I_{n p}^{2}+i_{m(r m s-D C)}^{2}+2 I_{n p} i_{m(r m s-D C)} \sin (\varphi) .
$$

This approach was applied, in particular, in [15] when calculating the losses and the temperature rises of the windings of transformer TDC rated for 400 MVA. Permissible GIC currents were determined at various levels of the transformer initial load. However, at evaluation of the tank temperature rises, the losses due to rated currents are considered as insignificant, and calculation was carried out only taking into account $\mathrm{MC}$.

Increase factors of the losses due to higher harmonics. In presence of higher harmonics in the magnetic field, the values of losses as for the first harmonic should be increased [17], [18]: when calculating the ohmic losses in the windings they should be multiplied by the factor $k_{i^{2} R}$, in the winding conductors and in non-magnetic structural elements - by the factor $k_{N}$, in structural parts made of ferromagnetic steel - by the factor $k_{F}$

$$
k_{i^{2} R}=\sum_{n}^{K} i_{n}^{\prime 2}, k_{N}=\sum_{n}^{K} i_{n}^{\prime 2} \cdot n^{2}, k_{F}=\sum_{n}^{K} i_{n}^{\prime 2} \cdot n^{0.85} .
$$

The values of these factors at different DC currents are given in tab. 1.

At evaluation of the factors related to the winding conductors and the structural conductive parts made of non-magnetic steel as for the frequencies specified, the assumption is made about insignificant demagnetizing effect of eddy currents.

At calculation of increase factor of the losses in structural steels with non-linear surface effect, in particular, in the tank, the exponent can take the different values: slightly higher and less than the unity, in the region of «weak» and «strong» fields, respectively [17]. For conditions of the transformer under study, the exponent of 0.85 is assumed, which was determined from the equality of calculated losses in the tank using factor (6) and the sum of losses due to current harmonics.

Thus, for the case of orthogonal property of the vectors of the windings rated currents and the vectors of the harmonic components of peak unbalanced MC, loss calculation of the transformer exposed to GIC using analytical methods is conducted in three stages. At the first stage the calculation of the magnetic field and the losses Pn is carried out at rated balanced currents in $\mathrm{HV}$ and $\mathrm{LV}$ windings in case of unsaturated MS. At the second stage, calculation is performed for the magnetic field and the losses $\mathrm{P}_{1}$ due to the current of $\mathrm{MC}$ first harmonic in $\mathrm{HV}$ windings in case of saturated MS of the transformer. At the third stage the total and the local losses are to be added using the appropriate factors (6)

$$
P_{G I C}=P_{n}+k P_{1} .
$$

When calculating the temperature rises in the windings, computational and empirical methods are used [18], which stipulate the averaged coefficients of heat transfer to oil depending on a number of design factors, temperature of cooling oil and heat flux density to be determined from the total losses (7). 
When calculating the temperature rises of the structural elements, the coefficients of heat transfer should be also determined [19], [20] by aerial density of the total losses. Simplistically, assuming that the coefficients of heat transfer in the studied modes are unchanged, the temperature rise estimates can be carried out according to the modes, and then summed up similar to the expression (7).

Magnetic field in the active part. Using the 2D FEM model, the magnetic field was calculated in the section along the transverse axis of the transformer phase for rated currents in LV and HV windings - fig. 6a, and due to $\mathrm{MC}$ first harmonic in $\mathrm{HV}$ winding - fig. $6 \mathrm{~b}$.

At calculations, the model core, magnetic shunts on the tank are characterized by normal magnetization curve of electrical steel, the yoke beams are described by constant values of magnetic permeability. Comparison of the presented cases demonstrates the difference in magnetic fields depending on above two conditions in the winding region and at the model boundaries, that is, on the core and on the simplified surface of the tank with a magnetic shield (shunts).

At rated current mode of the windings (fig. 6a) the flux lines of leakage field are concentrated in the main duct between the windings. The maximum value of axial component of the magnetic field induction is equal to 310 mTesla. Uncompensated magnetic field of MC first harmonic $\mathrm{I}_{1}=i_{1} / \sqrt{2}=13.8$ A (fig. $7 \mathrm{~b}$ ) has a pronounced solenoidal nature. Axial component of induction at inner vertical generatic line of $\mathrm{HV}$ winding has a small value 12 mTesla.

Neglecting the influence of simplified models of the yoke beams and the tank with shunts on the magnetic field in the region of the windings and the core, the analytical calculation of the magnetic field components in these regions is performed by axisymmetric M-CC model presented in Section II.

The internal and external, with respect to the windings, ferromagnetic cylinders of the calculation model are characterized by constant permeability values across the cross. Under certain conditions, these values of magnetic permeability can take the extreme magnitudes of air medium (complete magnetic saturation), of unsaturated ferromagnet with high value of magnetic permeability, or the finite value, which depends on the degree of the electrical steel saturation. Horizontal slot walls are ideal ferromagnetic half-spaces. The expressions for radial and axial components of the magnetic field induction and the inductances of the circular elements (parts of the windings) are determined from the solution of the corresponding boundary value problem in the form of Fourier series using axial coordinate, and Bessel functions using radial coordinate.

For the rated mode, the value of relative magnetic permeability of the internal ferromagnet (the core) is assumed to be 1000 , and at MC mode in HV winding, the magnetic permeability is taken to be equal to 3 (according to calculation results of nonlinear model shown in fig. $6 b)$, i.e., core saturation is taken into account. For both modes, the tank effect is neglected.

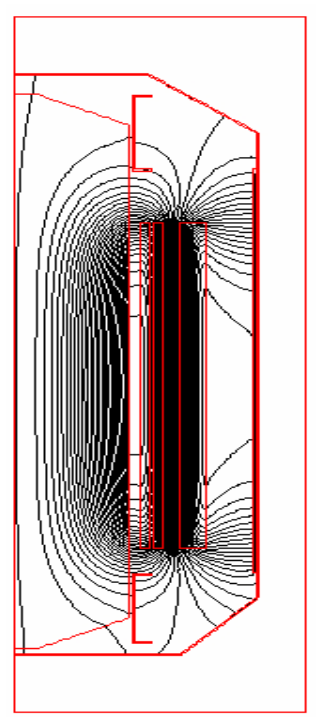

a)

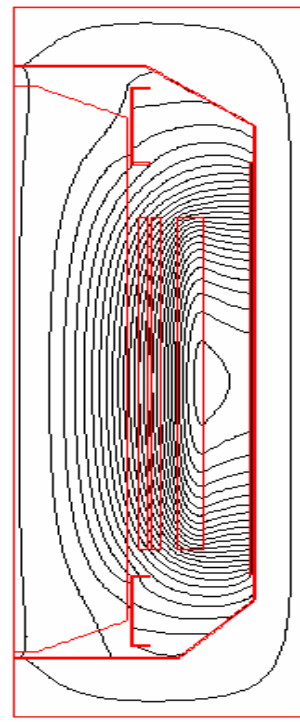

b)
Figure 6. Flux lines for conditions of rated currents in the windings (a), and for excitation current in HV (b)

Based on calculation results in fig. 7 the red line shows alternating-sign distribution of induction normal component of the magnetic field as referred to MS surface at rated mode, and the line with dots - for MC mode in HV. The values are shown in per units relative to maximum magnitudes, 147 and 34 mTesla, respectively. Specified values of the magnetic field induction are used for calculation of the eddy currents and the losses in the extreme lamination stack, and in the pressing plate on MS core, as well as for evaluation of the losses in the yoke beams.

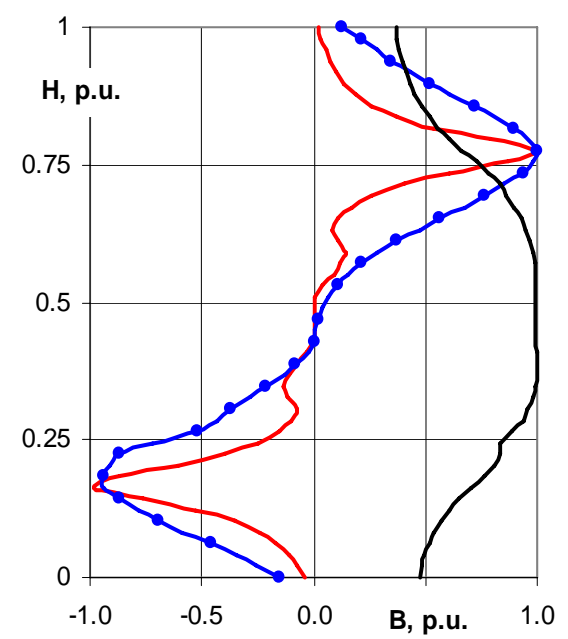

Figure 7. Distribution of the magnetic field induction components along the height of MS pressing plate and the extreme lamination stack.

The black line in fig. 7 shows distribution of axial 
component of $\mathrm{HV}$ winding MC magnetic field induction along the height of pressing plate. The values are reduced to maximum magnitude $10 \mathrm{mTesls}$, which is closely equal to intensity of magnetic field axial component at the edge of $\mathrm{HV}$ winding. Presence of this magnetic field induction component contributes to generation of additional eddy currents in the pressing plate, which are not available in the nominal leakage fluxes of the transformers.

Total losses, temperature rises of the tank oil. Thermal calculations of the elements of the active part and the transformer tank are preceded by calculation of total loss and oil temperature rises in the tank [18]. In this case, empirical estimates of total additional losses in the structure "by analogy" are widely used, which are subsequently adjusted by element-wise calculation [18], [20]. Information related to total loses in the transformer allows calculation of oil temperature distribution in the tank in accordance with cooling system type employed. So, for the studied transformer at AC mode using appropriate software [20], the temperature rises of middle and top oil in the tank above the ambient temperature (ACMT) were determined: 33 and $35 \mathrm{~K}$, as well as thermal time constant of the transformer was estimated as equal to 2.5 hours. Specified temperature rises are summed according to overheating method with temperature rises above oil of windings, core, structural elements, with evaluation of exceeding of their temperatures above ACMT, which is finally compared with appropriate standard values [1].

Losses, temperature rises in the windings. For nominal conditions, calculation of ohmic losses and additional losses due to eddy currents in the winding conductors is widely-known [17] and carried out using the appropriate software [20].

For a non-sinusoidal MC at DC mode, this calculation is carried out in two forms. The first form is the sum of ohmic losses due to current harmonic components and additional losses due to eddy currents as used in such cases. The second form stipulates the losses due to the first harmonic, multiplied by the factors (6) for ohmic losses and eddy current losses. It should be noted that in this case only additional eddy current losses due to $\mathrm{MC}$ magnetic field in HV winding are generated in LV winding. As referred to $\mathrm{HV}$ winding, it is required to add also ohmic losses due to MC zero-component, that is, from DC current. Comparison of the results has demonstrated the practical coincidence of the results of calculations of both forms.

In case of known losses in the windings and temperatures of the cooling oil in the tank, temperature rises of the transformer coil windings were calculated using the industry-specific empirical methodology [20] for OFAF cooling mode. In particular, for rated AC mode it was determined that $\mathrm{HV}$ winding has the maximum temperature rise. Temperature rise over ACMT of HV winding average temperature makes up $63 \mathrm{~K}$, and hot spot temperature $-77 \mathrm{~K}$. These values do not exceed standard (normalized) magnitudes: 65 and $78 \mathrm{~K}$, respectively [1].

For DC mode, the performed calculations demonstrated slight (by tenths) increase of temperature due to previously specified low intensities of the currents and the magnetic fields. However, it was determined that even at DC current value of $50 \mathrm{~A}$, the specified temperature rises has reached the values of 67.3 and $81.8 \mathrm{~K}$, which exceed the standard (normalized) magnitudes.

Circulating currents in the windings. Possible increase in currents and losses due to circulating currents but at significant DC current levels 100/3 A is highlighted in [8]. For the transformer under study, the previously specified low magnetic field intensities at DC mode do not result in such problems.

In this regard, it should be noted, that for MC solenoidal magnetic field, the well-known method for calculation of current distribution in complex circuits with limped ohmic resistance and inductance [18] is employed. In this case, the inductances should be evaluated with consideration of appropriate magnetic permeability of the calculation model core.

Losses and temperature rises in the core pressing plate. To restrict the eddy currents and the losses the pressing (lifting) strip on the MS core is made of nonmagnetic steel with vertical notches. In case of AC mode at rated currents in the windings, the eddy currents closed in the winding plane are calculated for two-dimensional plate model by analytical method using Fourier series [20]. Magnetic induction component normal to the plate surface is the effecting factor, and its distribution is shown in fig. 7. To calculate temperature distribution within the plate, analytical three-dimensional method is also used having the special function of three-dimensional distribution of losses. Solution of respective thermal problem is presented as expansion in series of the function in question according to eigen functions [20].

More accurate calculations, taking into account the vertical notches in the plate, can be performed using the numerical simulation. Fig. 8 shows distribution of density of eddy currents and losses at upper part of the pressing strip. Maximum value of losses and, respectively, temperature rises are evident at the strip edge at the area of maximum magnetic field, i.e., against the winding end surface.

It should be noted, that for MC the eddy currents generated under effect of magnetic field induction (fig. 7) and the currents closed along the plate cross-section should be additionally evaluated, for example, using [17].

For resultant $\mathrm{AD}$ mode under GIC effect the losses in the plate due to rated current magnetic field and MC are added according to expression (7).

Based on calculations the maximum temperature rises above ACMT at the edges of individual strip of the pressing plate for $\mathrm{AC}$ and $\mathrm{AD}$ modes are obtained as 50 and $63 \mathrm{~K}$, in view of standard (normalized) value of $75 \mathrm{~K}$.

Losses in the extreme stack of MS core. Losses and temperature rises in the extreme stack of the core are calculated similar to method for non-magnetic pressing plate. In this case the calculated thickness of stack is determined based on empirical dependence as for electric steel lamination layer considering its dimensions and maximum amplitude of effecting magnetic field normal to 
lamination (fig. 8). It should be noted, that for extreme stack the losses in electric steel due to magnetic flux in MS core are to be additionally considered [20] for nominal conditions and for saturated steel, respectively. Maximum temperature rises of the extreme stack above ACMT for AC and AD modes are obtained: 41 and $52 \mathrm{~K}$, in view of standard (normalized) value of $75 \mathrm{~K}$.

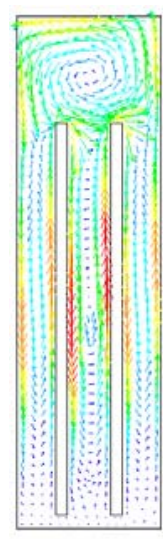

b)

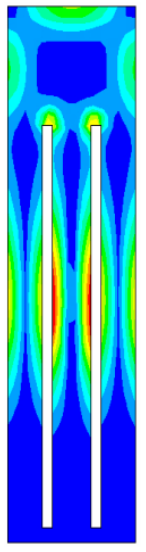

Figure 8. Distribution of eddy currents (a) and losses (b) in pressing plate with notches

Losses, temperature rises of the tank. For the purpose of calculation the numerical- analytical quasi-threedimensional calculation model of the transformer is used - fig. 9.

The well-known method of surface losses [20] is employed. This method stipulates two stages. At the first stage, the spatiotemporal distribution of the primary magnetic field in the air along the closed path, which coincides with the surface of the tank (without the tank), is calculated. Superposition of axisymmetric magnetic fields of individual cores (phases) is used - the M-CC model. At the second stage, using the non-linear coefficients of the effect of impedance type, the tangent component of the magnetic field intensity on the tank surface is determined. Using the square of its value and the real component of the empirical characteristic of surface resistance, the losses are calculated for the specific vertical sections of the tank. The local factors of the primary field variation in the region take into account presence of discrete stacks of electrical steel (shunts) on the tank internal surface.

The software used [20] has graphic pre- and postprocessors for representing the geometry of the calculation model and the results of calculations. Fig. 9a shows the horizontal axial lines $0 x, 0 z$, the reference lines of the centers of cores and windings as referred to the axial lines, the circular contours of cores and windings. The line of lower calculated tank contour, which is almost in contact with the contours of the core is shown along $0 z$ axis.

Isometric simplified diagram in fig. $9 \mathrm{~b}$ shows the model vertical axis $0 y$, the phantom sections of cores and windings. Calculated surface of the tank is generated by horizontal surface along the tank bottom, then by inclined plane from the windings, further by vertical wall, again by inclined line to the windings and horizontal part on the cover.

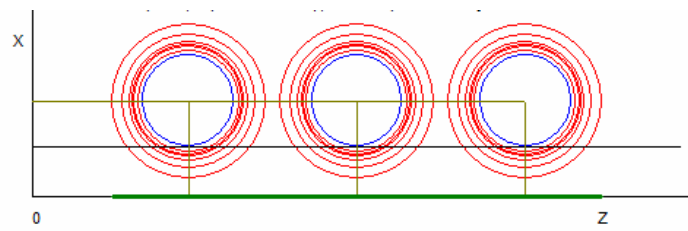

a)

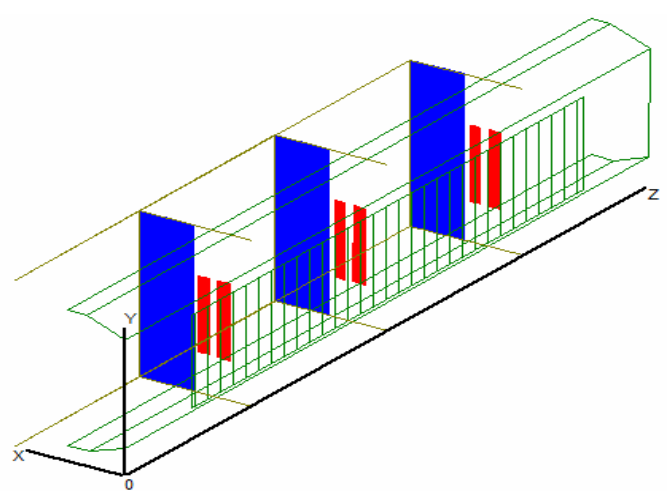

b)

Figure 9. Simplified diagram of projection onto horizontal plane (a) and isometric simplified diagram (b) of quasi-three-dimensional model of the transformer for calculation of losses in the tank

The grid of vertical lines shows the position of the magnetic shunts on the tank longitudinal wall. The tank butt end parts are not considered, since they are shielded from the magnetic field of the windings by MS lateral yokes. Forty vertical sections are set on the tank wall, each of them has 50 points along the height; point 50 corresponds to the tank bottom.

Distribution of the temperature rise on the tank surface above adjacent oil temperature is represented in fig. $10,11$.

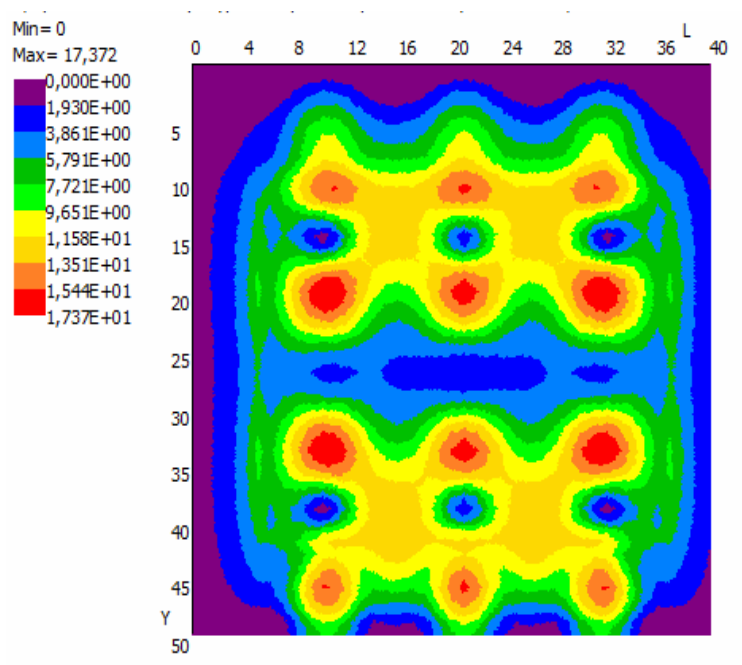

Figure 10. Distribution of temperature rises on the tank surface above adjacent oil at rated current mode in the the windings 
For MC first harmonic in HV (fig. 11), maximum values of order of1.3 $\mathrm{K}$ are observed on the upper part of the tank in the areas between the phase cores, approximately in 10 horizontal points at vertical generators (15 and 25). It should be noted that at these points the temperature rises due to rated currents in the windings make up about $12 \mathrm{~K}$.

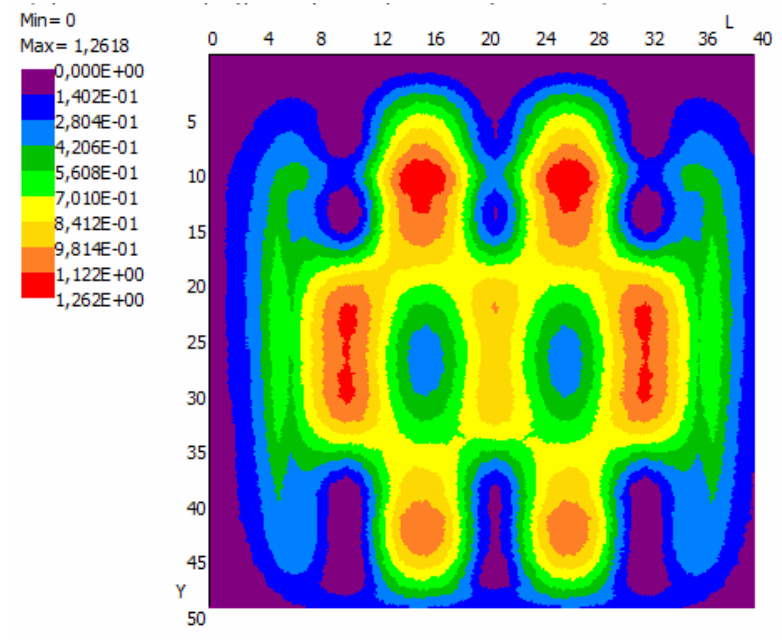

Figure 11. Distribution of temperature rises on the tank surface above the temperature of adjacent oil in case of $\mathrm{MC}$ in $\mathrm{HV}$

Fig. 10 demonstrates maximum value of $17.4 \mathrm{~K}$ at rated currents in the windings which occur in the upper and middle part of the tank within the areas adjacent to the phase windings, approximately in the points 10, 19 and 33 on the vertical generatrix 20 .

Expression (7) with the factor $\mathrm{k}_{\mathrm{F}}=7.5$ (tab. 1) allows to carry out the tentative estimate of temperature rise above oil at cumulative mode: $12.0+1.3 * 7.5=22 K$. Since these points correspond to the tank upper part, the value obtained should be added by temperature rise above top oil ACMT in the tank: $22+35=57 \mathrm{~K}$, which nevertheless will be lower if compared with standard (normalized) value of $75 \mathrm{~K}$.

It is determined by calculations that the total losses in the tank due to rated currents in the windings are 68 $\mathrm{kW}$. The losses due to $\mathrm{MC}$ in $\mathrm{HV}$, the second term in the sum (7), are $33 \mathrm{~kW}$. Thus, at AD mode, the losses in the tank are equal to $101 \mathrm{~kW}$.

Losses, temperature rises of the yoke beams. Active part of the transformer contains the yoke beams located at the top and the bottom of the windings, the vertical walls made of ferromagnetic steel with non-linear skin effect, and the horizontal shelves of contoured profile made of non-magnetic steel.

Taking into account the degree of complexity of electromagnetic processes in the welded beams, the finiteMS model was also simplified. In the plane of electric steel laminations, MS cores and yokes are characterized by normal magnetization curve. According to the normal to MS laminations, the magnetic permeability is determined taking into account the stacking factor of steel, and it represents the constant finite element modeling method was used to calculate the losses in yoke beams [20]. Simplified diagram of FEM model of the transformer under study is shown in fig. 12 with simplified (without insert) tank cap.

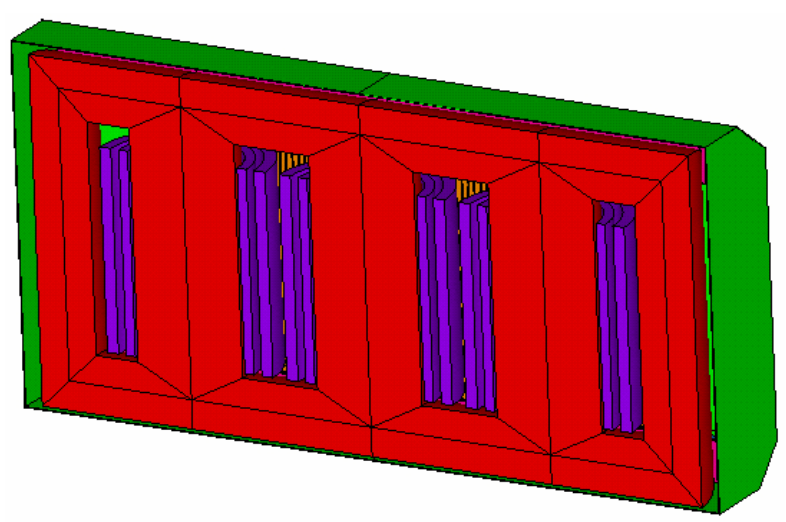

Figure 12. Simplified drawing of three-dimensioned finite-element model of the transformer

The magnetic shunts on the tank walls concentric with winding cores are taken into account. The tank and the vertical walls of the yoke beams are characterized by normal magnetization curve of structural steel and by constant value of electrical conductivity. Welded joint of ferromagnetic walls and non-magnetic shelves is taken into account by natural contact conditions of the beam FEM models.

For the tank and the yoke beams, the volumetric loss method was used, in which the volumetric losses for eddy currents and hysteresis in ferromagnetic structural steels are summarized [20].

The obtained calculated distribution of losses in ferromagnetic walls of upper (continuous) and lower (simply-supported) beams is shown in fig. 13 .

At rated current mode, the eddy current losses in the non-magnetic shelf of upper beam are $3.8 \mathrm{~kW}$, in the ferromagnetic wall $-4.4 \mathrm{~kW}$ and $0.7 \mathrm{~kW}$ for hysteresis.
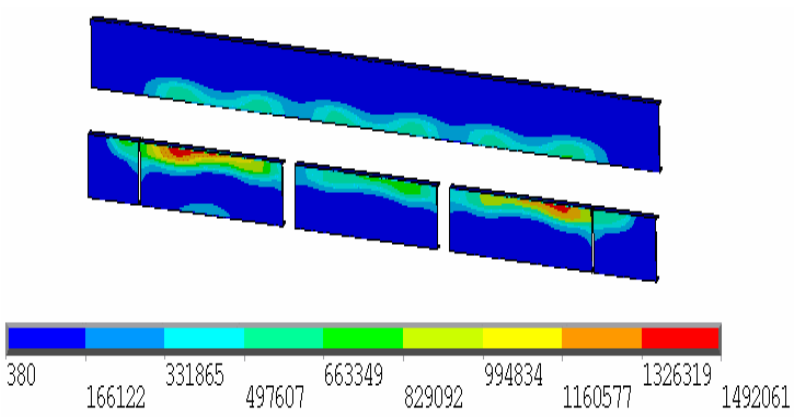

Figure 13. Distribution of volumetric losses $\left(\mathrm{W} / \mathrm{m}^{3}\right)$ at surface layer of ferromagnetic walls of the yoke beams due to rated current mode of the windings 
In this case, maximum local losses occur due to eddy currents in a relatively narrow shelf (but with a considerable thickness) of the beam, at the point of its welding with the vertical wall. Temperature rise of the tank above oil temperature at specified location makes up 23 K. Therefore, in total with temperature rise of top oil above ACMT $35 \mathrm{~K}$, maximum temperature rise above ACMT of upper beam makes up $23+35=58 \mathrm{~K}$, which is less than the permissible value of $75 \mathrm{~K}$.

At MC mode, the beam temperature rise is approximately estimated as follows. The ratio of magnetic field on MS core surface is used, i.e., practically in the region of beam location, which is given in explanations to fig. 7 . It states that at rated current mode the magnetic field induction component normal to the core surface is 147 mTesla, but at DC current mode it is 34 mTesla. That is, the ratio $34 / 147=0.23$ allows to estimate the losses in the shelf at this mode by the value $3.8 * 0.232=0.2 \mathrm{~kW}$. Using expression (7) and factor 7.5 for non-magnetic steel from Table. 1, the temperature rise of the beam above oil temperature is determined at total loss mode as $23+7.5 *$ $23 * 0.2 / 3.8=32 \mathrm{~K}$ and above ACMT - as $32+35=$ $67 \mathrm{~K}$.

Losses, temperature rises in the tank and in the tank cover. At rated mode the total loses in the tank FEM-model in fig. 12 made up $73 \mathrm{~kW}$, which corresponds to the results of analytical calculation $(68 \mathrm{~kW})$. As shown using the model in fig. 9, increase of the losses in the tank due to $\mathrm{MC}$ in $\mathrm{HV}$ winding up to $101 \mathrm{~kW}$, leads to increase of maximum temperature rise of the tank surface above ACMT up to $57 \mathrm{~K}$, that is much less than standard (normalized) value of $75 \mathrm{~K}$. Thus, at the given mode FEM-model in fig. 12 was not employed, but evaluation of losses and temperature rises in the tank cover was made using FEM-model improvement.

Mentioned FEM-model was supplemented by LV leads and by cover model with insert made of nonmagnetic steel with rectangular notches - fig. 14 .

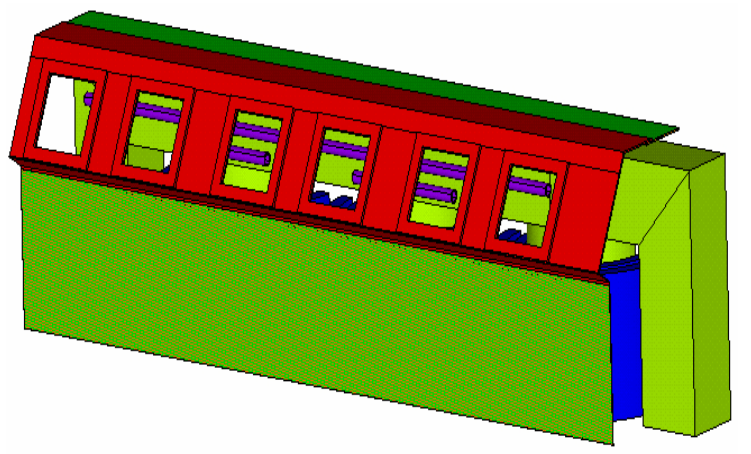

Figure 14. Tank model with notches for leads in nonmagnetic-steel insert

During type testing at the locations of loss concentration, the maximum temperature rises of insert surface temperature above ACMT was defined by thermal imaging camera, it was equal to $78.8-20=58.8 \mathrm{~K}$ (fig. $15 \mathrm{~b})$, that is close to calculated value of $58.1 \mathrm{~K}$.

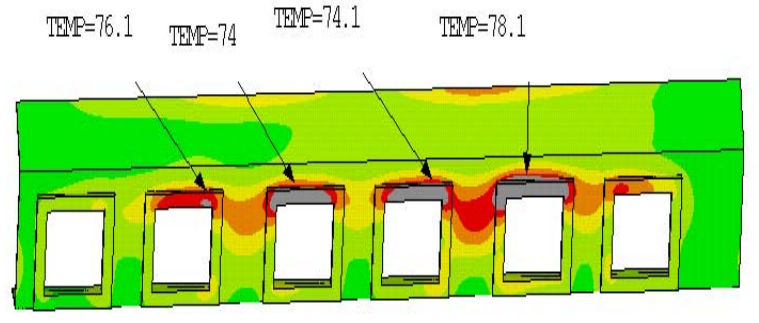

a)

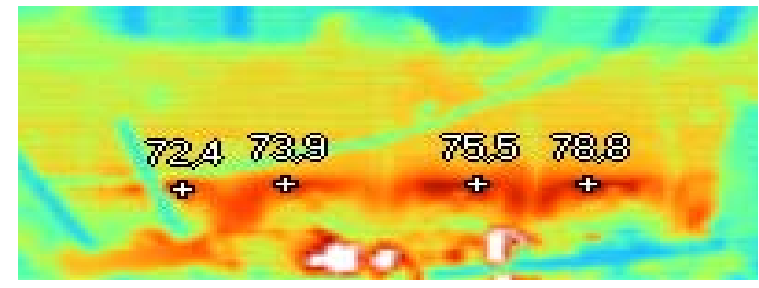

b)

Figure 15. Distribution of calculated (a) and measured (b) temperatures on the tank cover

Taking into account the available margins for temperature rise at rated mode, and since the losses in the cover are dependent mainly on the currents of LV lead, which are unchanged, no evaluation of temperature rise of the cover was carried out at DC level $10 \mathrm{~A}$.

Note that in this section the approach to calculation of winding currents, magnetic fields, and losses is somewhat simplified with respect to the currents of MC third and its multiple (odd) harmonics, transformed from $\mathrm{HV}$ winding and closed in LV winding in case of deltaconnected circuit [21]. The magnetic fields of these harmonics would need to be determined with a saturated core, but due to the currents of these harmonics, both in LV and HV. It should be borne in mind that their ampereturns are not equal due to non-perfect magnetic coupling of the windings arranged on saturated core. Such currents would determine some average distribution of power lines between fig. $6 \mathrm{a}$ and fig. $6 \mathrm{~b}$. In this field it would be necessary to determine the appropriate losses. With significant $\mathrm{MC}$ value, the possible increase in losses in the tank cover due to transformation of third and its multiple harmonics into the winding and leading away of LV should be considered. In this paper, the specified phenomenon is not taken into account due to low values of MC.

Losses, temperature rises in the magnetic system. Fig. 16a shows distribution of magnetic induction in MS central stacks at the timepoint of maximum voltage amplitude at the extreme phase in case of rated AC mode. The value of magnetic induction is close to 1.7 Tesla in the cores, and 1.4 Tesla - in the yokes. The losses in the transformer MS are determined using the specific losses of electrical steel in MS uniform areas, and in the zones of the lamination re-stacking - taking into account the appropriate loss increase factors [18]. 


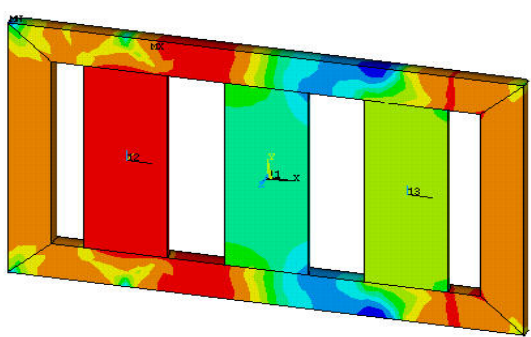

a)

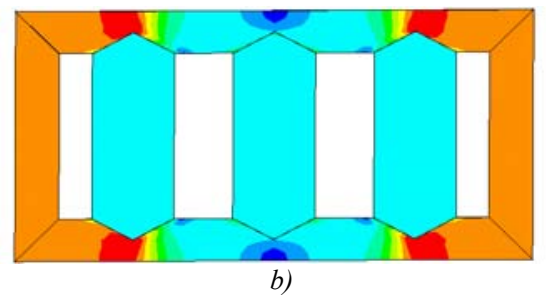

Figure 16. Induction distribution in MS central stacks at rated mode (a) and due to magnetic field of DC currents (b)

The nature of induction distribution in the considered transformer MS due to magnetic field of DC currents in HV windings of three phases is shown in fig. 16b. DC magnetic flux induction is 0.4 Tesla in the cores, and 0.6 Tesla in the lateral yokes. Unidirectional magnetic flux in the cores due to DC current during one of half-periods of $\mathrm{AD}$ mode is superimposed on the main magnetic flux in the transformer MS cores and leads to half-period saturation of the cores and to generation of magnetizing current in $\mathrm{HV}$ winding (fig. 2). In this case saturation of MS horizontal and vertical yokes is also took place.

In current times, loss calculation at $\mathrm{AD}$ mode is sophisticated due to insufficient knowledge of the complex half-period back magnetization of steel along «shifted» partial hysteresis (flux current) loop [11]. Therefore, in this paper the experimental data [11], [13] are employed for evaluation of the losses, according to which the increase in MS losses due to DC currents can reach about $30 \%$.

When designing the transformers, it is mandatory to verify conformity of temperature rises of core inner stacks and the yokes with the requirements of the standard [1]. To limit temperature rises, the core of the considered transformer MS was designed with vertical cooling ducts. During thermal calculations, the groups of stacks separated by cooling ducts were replaced by equivalent rectangles with uniform losses in the cross-section, having anisotropic thermal conductivity and non-uniform heat transfer conditions [20].

At rated mode the maximum value of temperature rise of the core internal stack surface above ACMT was evaluated as $68 \mathrm{~K}$, which is less than the value $75 \mathrm{~K}$. Loss increase by $30 \%$ for the given GIC level at steady-state thermal mode is resulted in temperature rise value of $74 \mathrm{~K}$ above ACMT.

Noise, vibration. The transformer noise at rated AC mode was calculated using the method of empirical calculation [20]. It was evaluated, in particular, that the sound level of the transformer under study at so-called distance $0.3 \mathrm{~m}$ made up $78 \mathrm{dBA}$. However, this method is insufficient for similar calculation to be performed for $\mathrm{AD}$ mode. Therefore, increase in sound level under effect of GIC can be evaluated using the known experimental data.

For example, the report [9] presents (fig. 17) the sound pressure dependences for single-phase transformer 374 MVA $/ / 525 / \sqrt{3} \mathrm{kV}$, measured at different DC currents and at two values of nominal induction in MS core.

Even at DC current $2 \mathrm{~A}$, the increase in sound level reaches $15 \mathrm{dBA}$, that is, about $22 \%$, and small increases were observed at DC current 3.5 A. As stated in [13], the increase in sound level by $30 \%$ was also measured at DC current $2 \mathrm{~A}$, and up to $33 \%$ at DC current DC $3.5 \mathrm{~A}$ for the group of three single-phase autotransformers rated for capacity 134.4 MVA, with guaranteed value of sound level $69 \mathrm{dBA}$ at rated induction in the core $1.717 \mathrm{~T}$.

Thus, assuming approximately specified increase in sound by 1.3 times for the transformer under study, the sound level under effect of GIS is evaluated as the value about $100 \mathrm{dBA}$.

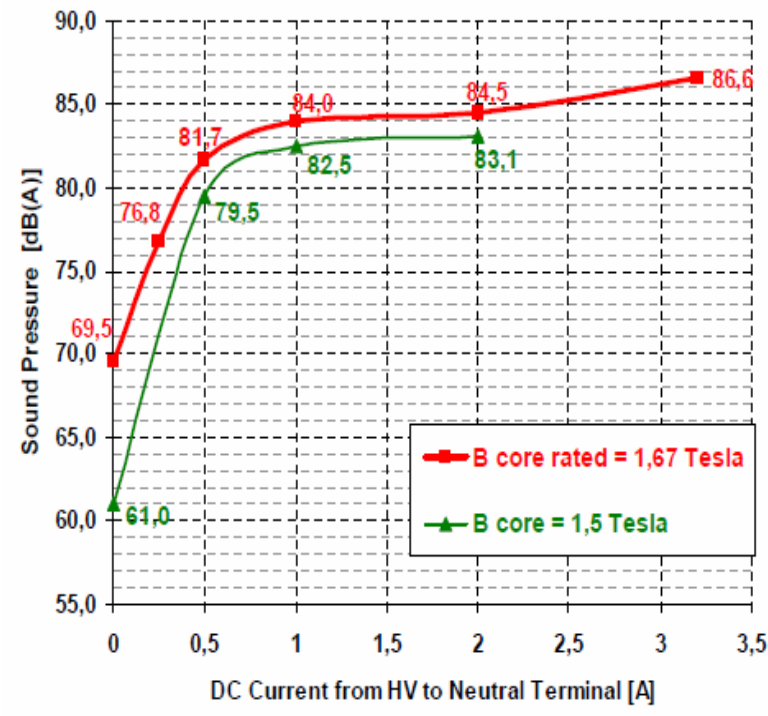

Figure 17. Dependences of sound level at different DC currents and at two values of rated induction in MS core for single-phase transformer $374 \mathrm{MVA} / / 525 / \sqrt{3} \mathrm{kV}$

Increase in magnetostrictive forces during magnetic biasing can also lead to increase in vibration as referred to the tank walls and the elements attached. Testing of the transformer under study has demonstrated a considerable margin as for vibration levels, which allows assuming that under effect of specified geomagnetic induced current, the maximum values of vibration will also not exceed the permissible magnitudes. 


\section{V.CONSTRUCTIVE MEASURES FOR IMPROVEMENT OF GEOMAGNETIC WITHSTAND STRENGTH OF POWER TRANSFORMERS}

In the events of GIC effects, to improve geomagnetic withstand strength of high-power transformers, the constructive measures sufficiently well-known at present time [17] - [20] can be taken.

The main measures of such nature are put in mind below:

in the windings - decrease of the losses owing to use of transposed conductors and the best compromise between the height and the width of conductor strands, by the effect of application of effective transposition schemes; decrease of temperature rises by means of enhancement of heat transfer, for example, owing to internal vertical cooling ducts, arrangement of labyrinth-type oil flow in the coil windings;

in the extreme stack of MS core - decrease of the losses by reduction of lamination width; decrease of temperature rises at lamination edge by means the cooling duct adjacent to the extreme stack;

in the pressing (lifting) plate of MS core - minimization of cross-section owing to reduction of axial pressing forces of the windings and width decrease for individual strips of the plate;

in the yoke beams - minimization of parts' dimensions made of ferromagnetic and non-magnetic steel owing to reduction of the forces and optimization of the winding pressing design, use of magnetic shields;

in the tank - application of combined magnetic shielding scheme of horizontal and vertical shunts with increased cross-section;

in the tank covers - provision of non-magnetic steel inserts in the covers, enlargement of distance between the leads and the cover surface, close arrangement of the leads of different phases, segregation of the leads into parallel conductors, application of electromagnetic shields, installation of magnetic field dividers in nonmagnetic inserts in the form of electric steel stacks;

in the magnetic system - decrease of the losses by means of use of electrical steel grades with minimum specific losses and application of high-performance stacking schemes, for example, step lap type; cooling with internal cooling ducts.

To reduce the transformer noise and vibration, it is recommended to use electrical steel grades with low level of magnetostriction, step lap stacking schemes, minimization of air gaps at the lamination joints, high-performance pressing of MS parts, special processing (conditioning) and pressing of the windings, including pressing by means of hydro-spring systems, reinforcement of the tank stiffeners and fastening of the attached elements, noise control of the cooling systems (low-noise fans), acoustic insulation of the transformer using the noise-mitigation shields.

\section{CONCLUSIONS}

1. It is demonstrated by the calculations that direct current of 10 A generated in HV winding under effect of geomagnetic induced currents does not lead to considerable increase in losses and temperature rises in the windings of the considered five-core transformer rated for capacity of 630 MVA. Maximum increase in the temperature rise over ACMT, the same as noted in the standard [1], takes place in non-magnetic pressing plates - from 50 $\mathrm{K}$ at rated mode, up to $63 \mathrm{~K}$ under GIC effect, in the extreme stacks of MS cores - from $41 \mathrm{~K}$ up to $52 \mathrm{~K}$. To a lesser extent increase is taken place for the temperatures above ACMT in the core internal stack - from $68 \mathrm{~K}$ up to $74 \mathrm{~K}$, in the yoke beams - from $58 \mathrm{~K}$ up to $67 \mathrm{~K}$, and in the tank walls - from $47 \mathrm{~K}$ up to $57 \mathrm{~K}$. Temperature rise of non-magnetic insert in the tank cover can be considered practically unchanged.

The considerable enhanced sound level of the transformer is observed - from 78 up to $100 \mathrm{dBA}$.

2. Calculation results and their comparison with the standard (normalized) values confirm the withstand strength of the transformer under study to the effects of specified geomagnetic induced currents based on operating conditions. Constructive measures are recommended for enhancement of such withstand strength.

3. For the case of orthogonal property of the vectors of the windings' rated currents and the vectors of the harmonic components of peak unbalanced $\mathrm{MC}$, the method of calculation of Joule losses was proven as the sum of losses generated due to these currents, using the increase factors for ohmic losses, losses in non-magnetic and ferromagnetic parts of the structure, which depend on the harmonic spectrum of magnetizing current.

\section{REFERENCES}

[1] IEC 60076-7. (2018). Power transformers - Part 7: Loading guide for mineral-oil-immersed power transformers, 89 .

[2] Bolduc, L., Aubin, J. (1977/1978). Effect of direct currents in power transformers. Part I. A general theoretical approach. Electric Power Systems Research, 1, 291-298.

[3] Bolduc, L., Aubin, J. (1977/1978) Effect of direct currents in power transformers. Part II. Simplified calculations for large transformers. Electric Power Systems Research, 1, 299-304.

[4] Chistiakov, H.N., Sihaev, S.N. (2011). Eksperimentalnoe issledovanie toka $\mathrm{v}$ neitrali transformatora $\mathrm{V}$ period heomahnitnykh bur. [Experimental study of the current in the neutral of the transformer during the period of geomagnetic storms]. News Tomsk Polytechnic University. Tomsk: State University, 318, 4, 122-127, (in Russian). Available: https://core.ac.uk/download/pdf/ 53067812.pdf.

[5] Effects of Geomagnetic Disturbances on the Bulk Power System. (2012). GMDTF Interim report: Nor- 
ton American Electric Reliability Corporation, 137.

Available: https://www.eenews.net/assets/2012/02/ 29/document pm 01.pdf.

[6] Gigris, R., Vedante, K., Gramm, K. (2012). Effects of Geomagnetically Induced on Power Transformers and Power Systems. CIGRE, Report A2-304, 8.

[7] Hershenhorn, A.I. (1993). Vozdeistviia heomahnitnykh tokov na elektrooborudovanie enerhosistem. [The effects of geomagnetic currents on electrical equipment of electrical energy systems]. Electric stations, 6, 54-63, (in Russian).

[8] Hurlet, P., Bertherau, F. (2007). Impact of geomagnetic induced currents on power transformer design. IEEE Conference MATPOST'07 - LYON, JST Transformateurs, France, 4.

[9] Klement, F., Leber, G. (2013). Designing for GIC withstand. Siemens: The Winning Transformers Indaba, 5-6 March, 1-21.

[10]Marketos, P., Moses, A.J., Hall, J.P. (2010). Effect of DC voltage on AC magnetization of transformer core steel. Journal of Electrical Engineering. 61, 7/s, . 123-125. Available: http://iris.elf.stuba.sk/JEEEC/ data/pdf/7s 110-34.pdf.

[11]Mousavi, S. A. (2012). Electromagnetic Modelling of Power Transformers with DC Magnetization. Sweden, Stockholm: Royal Institute of Technology (KTH), 86. ISBN 978-91-7501-537-8.

[12]Ngnegueu, T., Marketos, F., Devaux, F., Xu, T., Bardsley, R., Barker, S., Baldauf, J., Oliveira J. (2012). Behavior of transformers under DC/GIC excitation: Phenomenon, Impact on design/design evaluation process and Modelling aspects in support of Design. CIGRE, Report A2-303, 10.

[13]Passath, H., Leber, G., Hamberger, P., Bachinger, F. (2014). Direct current compensation - field experience under service conditions. Journal of Energy, vol. 63, Special Issue, 3-12. Available: http://www.hro-cigre.hr/downloads/casopis energija/ Journal of Energy_2014.pdf.

[14]Price, P. R. (2002). Geomagnetically induced current effects on transformers. IEEE Transaction on Power Delivery, 17, 4, 1002-1008. DOI: 10.1109/TPWRD.
2002.803710

[15]Vakhnina, V.V., et al. (2018). Mekhanizmy vozdeystviya kvazipostoyannykh tokov na elektricheskiye seti: monografiya. [Mechanisms of the impact of quasi-constant currents on electrical networks: a monograph] M.: Infra-Inzheneriya, 256, (in Russian). Available: https://books.google.com.ua/ books?isbn $=5041293384$.

[16]Zirka, S.E., Moroz, Y.I., Arturi, C.M., Bonnman, D. (2017). Topological transient models of three-phase five-core transformer. Electrical Engineering And Power Engineering, 2, 18-25. DOI 10.15588/16076761-2017-2-2.

[17]Leites, L.V. (1991). Elektromahnitnye raschety transformatorov i reaktorov. [Electromagnetic calculations of transformers and reactors]. Moskow: Enerhiia, 392, (in Russian).

[18]Biki, M.A. (2013). Proektirovanie silovykh transformatorov. Raschety osnovnykh parametrov. [Design of power transformers. Calculations of the main parameters]. Moskow: Znak, 612, (in Russian). ISBN 978-5-87789-070-1.

[19]Ivankov V.F., Basova A.V., Shulga N.V. (2014). Elektroteplovyye raschetnyye modeli elementov konstruktsii silovykh transformatorov. [Electricheating calculation models of structural elements of transformer equipment]. Electrical Engineering And Power Engineering, 2, 41-53, (in Russian). Available: http://nbuv.gov.ua/UJRN/etee_2014_2 8 .

[20]Ivankov, V.F., Basova, A.V., Khimiuk, I.V. (2017). Metody modeliuvannia transformatoriv ta reaktoriv. [Methods of modeling of transformers and reactors]. Kyiv.: Nash format, 490, (in Ukrainian). ISBN 978966-02-8297-1. Available: http://www.ied.org.ua/ files/monograf2 2017.pdf.

[21]IEEE Std C57.163-2015. IEEE Guide for Establishing Power Transformer Capability while under Geomagnetic Disturbances. 38.

\section{РОЗРАХУНОК ДІЙ ГЕОМАГНІТНИХ ІНДУКОВАНИХ СТРУМІВ НА ПОТУЖНИЙ СИЛОВИЙ ТРАНСФОРМАТОР}

IВАНКОВ В. $\Phi$. канд. техн. наук, начальник бюро ПрАТ «Запоріжтрансформатор», Запоріжжя, Україна, е - mail: Ivankov.Victor@gmail.com;

БАСОВА А. В. канд. техн. наук, провідний інженер ПрАТ «Запоріжтрансформатор», Запоріжжя, Україна, е - mail: awbasova@gmail.com;

Метою роботи є визначення стійкості потужного силового трансформатора до дій геомагнітних індукованих струмів та конструктивних заходів для ї̈ підвищення, при необхідності.

Методи дослідження. Застосовано аналітичний розрахунок струму намагнічування, який під дією геомагнітних індукованих струмів збуджується додатково до номінального струму в обмотиі вищої напруги. Використано аналітичні та чисельні методи розрахунку магнітного поля, втрат, розрахунково-емпіричні методи визначення нагрівів.

Отримані результати. Для пятистрижневого трансформатора потужністю 630 МВА при дї̈ гео- 
магнітних індукованих струмів визначені підвищені втрати і нагріви елементів конструкції на стрижнях магнітної системи, бака, підвищений рівень звуку.

Наукова новизна. Для випадку ортогональності векторів номінальних струмів обмоток $і$ векторів гармонічних складових пікоподібного незбалансованого струму намагнічування джоулеві втрати представлені сумою втрат від зазначених струмів з використанням коефічієнтів підвищення втрат омічних, в немагнітних і феромагнітних частинах конструкиії, які залежать від гармонійного спектру струму намагнічування.

Практична цінність. Підтверджено стійкість досліджуваного трансформатора до заданого рівня геомагнітних індукованих струмів, рекомендовані конструктивні заходи для ії підвищення. Апробовані методи можуть бути використані при розрахунковому проектуванні, при дослідженні реальних випадків експлуатаціі обладнання.

Ключові слова: трансформатори; геомагнітні індуковані струми; втрати; нагрів; розрахунки.

\section{РАСЧЕТ ВОЗДЕЙСТВИЙ ГЕОМАГНИТНЫХ ИНДУКТИРОВАННЫХ ТОКОВ НА МОЩНЫЙ СИЛОВОЙ ТРАНСФОРМАТОР}

ИВАНКОВ В. Ф. канд. техн. наук, начальник бюро ЧАО «Запорожтрансформатор», Запорожье, Украина, e-mail: Ivankov.Victor@gmail.com;

БАСОВА А. В. канд. техн. наук, ведущий инженер ЧАО «Запорожтрансформатор», Запорожье, Украина, e-mail: awbasova@gmail.com;

Целью работы является определение стойкости мощного силового трансформатора к воздействиям геомагнитных индуктированных токов и конструктивных мер для ее повышения, при необходимости.

Методы исследования. Применен аналитический расчет тока намагничивания, который под действием геомагнитных индуктированных токов возбуждается дополнительно к номинальному току в обмотке высшего напряжения. Использованы аналитические и численные методы расчета магнитного поля, потерь, расчетно-эмпирические методы определения нагревов.

Полученные результаты. Для пятистержневого трансформатора мощностью 630 МВА при воздействиях геомагнитных индуктированных токов определены повышенные потери и нагревы элементов конструкчии на стержнях магнитной системы, бака, повыменный уровень звука.

Научная новизна. Для случая ортогональности векторов номинальных токов обмоток и векторов гармонических составляющих пикообразного несбалансированного тока намагничивания джоулевы потери представлены суммой потерь от указанных токов с использованием коэффичиентов повышения потерь омических, в немагнитных и ферромагнитных частях конструкиии, которые зависят от гармонического спектра тока намагничивания.

Практическая ченность. Подтверждена стойкость исследуемого трансформатора к заданному уровню геомагнитных индуктированных токов, рекомендованы конструктивные мероприятия для ее повышения. Аnробированные методы могут быть использованы при расчетном проектировании, при исследовании реальных случаев эксплуатачии оборудования.

Ключевые слова: трансформаторы; геомагнитные индуктированные токи; потери; нагрев; расчеты. 